\section{A) Check for updates}

Cite this: Dalton Trans., 2020, 49 11346

Received 13th July 2020 , Accepted 3rd August 2020

DOI: $10.1039 / \mathrm{dOdt02466j}$ rsc.li/dalton

\title{
Structure and magnetism of the $\mathrm{Rh}^{4+}$-containing perovskite oxides $\mathrm{La}_{0.5} \mathrm{Sr}_{0.5} \mathrm{Mn}_{0.5} \mathrm{Rh}_{0.5} \mathrm{O}_{3}$ and $\mathrm{La}_{0.5} \mathrm{Sr}_{0.5} \mathrm{Fe}_{0.5} \mathrm{Rh}_{0.5} \mathrm{O}_{3} \dagger$
}

\author{
Nijat Hasanli, ${ }^{a}$ Alex Scrimshire, ${ }^{b}$ Paul A. Bingham, ${ }^{b}$ Robert G. Palgrave (iD c and \\ Michael A. Hayward (D) *a
}

\begin{abstract}
Synchrotron X-ray powder diffraction data indicate that $\mathrm{La}_{0.5} \mathrm{Sr}_{0.5} \mathrm{Mn}_{0.5} \mathrm{Rh}_{0.5} \mathrm{O}_{3}$ and $\mathrm{La}_{0.5} \mathrm{Sr}_{0.5} \mathrm{Fe}_{0.5} \mathrm{Rh}_{0.5} \mathrm{O}_{3}$ adopt distorted perovskite structures (space group Pnma) with $A$-site and $B$-site cation disorder. A combination of XPS and ${ }^{57} \mathrm{Fe}$ Mössbauer data indicate the transition metal cations in the two phases adopt $\mathrm{Mn}^{3+} / \mathrm{Rh}^{4+}$ and $\mathrm{Fe}^{3+} / \mathrm{Rh}^{4+}$ oxidation state combinations respectively. Transport data indicate both phases are insulating, with $\rho$ vs. $T$ dependences consistent with 3D variable-range hopping. Magnetisation data reveal that $\mathrm{La}_{0.5} \mathrm{Sr}_{0.5} \mathrm{Mn}_{0.5} \mathrm{Rh}_{0.5} \mathrm{O}_{3}$ adopts a ferromagnetic state below $T_{\mathrm{c}} \sim 60 \mathrm{~K}$, which is rationalized on the basis of coupling via a dynamic Jahn-Teller distortion mechanism. In contrast, magnetic data reveal $\mathrm{La}_{0.5} \mathrm{Sr}_{0.5} \mathrm{Fe}_{0.5} \mathrm{Rh}_{0.5} \mathrm{O}_{3}$ undergoes a transition to a spin-glass state at $T \sim 45 \mathrm{~K}$, attributed to frustration between nearest-neighbour Fe-Rh and next-nearest-neighbour Fe-Fe couplings.
\end{abstract}

\section{Introduction}

Transition-metal oxides which adopt the $\mathrm{ABO}_{3}$ perovskite structure exhibit a wide variety of complex physical properties, including superconductivity, colossal magnetoresistance, ferroelectricity and a wide variety of other coupled electronic and magnetic behaviours. ${ }^{1}$ The rich diversity of electronic and magnetic phenomena displayed by perovskite oxides can be attributed to the strong coupling between the local electronic states of the octahedrally coordinated transition-metal cations, which is facilitated by strong covalency in the $B-\mathrm{O}-B$ links which connect the $\mathrm{BO}_{6}$ units. $^{2}$

Recently there has been much interest in perovskite oxide compounds which combine $3 \mathrm{~d}$ and $4 \mathrm{~d}$ or $3 \mathrm{~d}$ and $5 \mathrm{~d}$ transition-metal cations, because the contrasting features of the $3 \mathrm{~d}$ (narrow metal d-bands, large on-site electron-electron repulsion) and $4 \mathrm{~d} / 5 \mathrm{~d}$ (broad d-bands, low on-site repulsion, strong spin-orbit coupling for $5 \mathrm{~d}$ ) cations can result in novel behaviour when they are combined. ${ }^{3,4}$ For example, $\mathrm{Sr}_{2} \mathrm{FeMoO}_{6}$ exhi-

\footnotetext{
${ }^{a}$ Department of Chemistry, University of Oxford, Inorganic Chemistry Laboratory, South Parks Road, Oxford, OX1 3QR, UK.E-mail: michael.hayward@chem.ox.ac.uk ${ }^{b}$ Materials and Engineering Research Institute, Sheffield Hallam University, City Campus, Howard Street, Sheffield, S1 1WB, UK

${ }^{c}$ Department of Chemistry, Department of Chemistry, University College London, 20 Gordon Street, London, WC1H OAJ, UK

$\dagger$ Electronic supplementary information (ESI) available: Mn 2P and Fe 2P XPS from $\mathrm{La}_{0.5} \mathrm{Sr}_{0.5} \mathrm{Mn}_{0.5} \mathrm{Rh}_{0.5} \mathrm{O}_{3}$ and $\mathrm{La}_{0.5} \mathrm{Sr}_{0.5} \mathrm{Fe}_{0.5} \mathrm{Rh}_{0.5} \mathrm{O}_{3}$ respectively; additional fits to ${ }^{57} \mathrm{Fe}$ Mössbauer data from $\mathrm{La}_{0.5} \mathrm{Sr}_{0.5} \mathrm{Fe}_{0.5} \mathrm{Rh}_{0.5} \mathrm{O}_{3}$. See DOI: 10.1039/ dodt02466j
}

bits half-metallic ferromagnetic behaviour attributed to the interaction between the localized $3 \mathrm{~d}^{5}$ electronic configuration of $\mathrm{Fe}^{3+}$ and the delocalized $4 \mathrm{~d}^{1}$ electrons of $\mathrm{Mo}^{5+},{ }^{5}$ with similar behaviour observed in other $3 \mathrm{~d} / 4 \mathrm{~d}$ and $3 \mathrm{~d} / 5 \mathrm{~d}$ systems. ${ }^{6,7}$

In a broader context the inter-cation magnetic couplings in mixed $3 \mathrm{~d} / 4 \mathrm{~d}$ and $3 \mathrm{~d} / 5 \mathrm{~d}$ perovskite oxides do not generally appear to follow the Goodenough Kanamouri rules ${ }^{8}$ which dominate $3 \mathrm{~d}$ systems. ${ }^{9-11}$ However, to date only a subset of the $3 \mathrm{~d} / 4 \mathrm{~d}$ and $3 \mathrm{~d} / 5 \mathrm{~d}$ perovskite oxide phases which could be envisioned have been reported, ${ }^{12}$ so it is hard to formulate broad magnetic coupling rules for this class of compound. To help address this situation, we have been studying mixed perovskite phases containing rhodium.

A range of Rh-containing perovskite oxides of the form $\mathrm{LaM}_{0.5} \mathrm{Rh}_{0.5} \mathrm{O}_{3}$ have been reported $(M=\mathrm{Cr}, \mathrm{Mn}, \mathrm{Fe}, \mathrm{Co}$, Ni and $\mathrm{Cu})$ with $M / \mathrm{Rh}$ cation disordered structures. ${ }^{13-16}$ The unit cell volumes of these $\mathrm{LaM}_{0.5} \mathrm{Rh}_{0.5} \mathrm{O}_{3}$ compounds are broadly consistent with an $\mathrm{M}^{3+} / \mathrm{Rh}^{3+}$ oxidation state combination, with the exception of $\mathrm{LaCu}_{0.5} \mathrm{Rh}_{0.5} \mathrm{O}_{3}$ which appears to adopt a configuration close to a $\mathrm{Cu}^{2+} / \mathrm{Rh}^{4+}$ combination. ${ }^{13,15}$ However, Curie constants obtained by fitting the Curie-Weiss law to temperature-dependent magnetization data deviate from values expected for combinations of $M^{3+}$ and low-spin, $S=0 \mathrm{Rh}^{3+}$, casting some doubt on this oxidation state assignment. ${ }^{13}$ In the case of $\mathrm{LaCo}_{0.5} \mathrm{Rh}_{0.5} \mathrm{O}_{3}$ the deviations are large and temperature dependent and have been attributed to both a change in the spin-state of $\mathrm{Co}^{3+}$ and the presence of $\mathrm{Co}^{2+} / \mathrm{Rh}^{4+}$ oxidation state combinations. ${ }^{17-19}$

Here we report two further cation-disordered rhodiumcontaining perovskite oxides, $\mathrm{La}_{0.5} \mathrm{Sr}_{0.5} \mathrm{Mn}_{0.5} \mathrm{Rh}_{0.5} \mathrm{O}_{3}$ and 
$\mathrm{La}_{0.5} \mathrm{Sr}_{0.5} \mathrm{Fe}_{0.5} \mathrm{Rh}_{0.5} \mathrm{O}_{3}$. Using a combination of XPS and ${ }^{57} \mathrm{Fe}$ Mössbauer spectroscopy we demonstrate that, even though these compounds were prepared at ambient pressure, the rhodium cations adopt an $\mathrm{Rh}^{4+}$ oxidation state, resulting in ferromagnetic behaviour for $\mathrm{La}_{0.5} \mathrm{Sr}_{0.5} \mathrm{Mn}_{0.5} \mathrm{Rh}_{0.5} \mathrm{O}_{3}$ and spinglass behaviour for $\mathrm{La}_{0.5} \mathrm{Sr}_{0.5} \mathrm{Fe}_{0.5} \mathrm{Rh}_{0.5} \mathrm{O}_{3}$.

\section{Experimental}

\section{Synthesis}

Samples of $\mathrm{La}_{0.5} \mathrm{Sr}_{0.5} \mathrm{Mn}_{0.5} \mathrm{Rh}_{0.5} \mathrm{O}_{3}$ and $\mathrm{La}_{0.5} \mathrm{Sr}_{0.5} \mathrm{Fe}_{0.5} \mathrm{Rh}_{0.5} \mathrm{O}_{3}$ were prepared via a high-temperature ceramic route. Suitable quantities of $\mathrm{La}_{2} \mathrm{O}_{3} \quad\left(99.999 \%\right.$, dried at $\left.900{ }^{\circ} \mathrm{C}\right) \mathrm{SrCO}_{3}$ (99.994\%), $\mathrm{Rh}_{2} \mathrm{O}_{3}\left(99.99 \%\right.$, dried at $\left.800{ }^{\circ} \mathrm{C}\right)$ and either $\mathrm{MnO}_{2}$ $(99.997 \%)$ or $\mathrm{Fe}_{2} \mathrm{O}_{3}(99.997 \%)$ were ground together in an agate pestle and mortar and then heated in air to $1000{ }^{\circ} \mathrm{C}$ in an alumina crucible. The resulting powders were then reground and pressed into pellets. Samples of $\mathrm{La}_{0.5} \mathrm{Sr}_{0.5} \mathrm{Mn}_{0.5} \mathrm{Rh}_{0.5} \mathrm{O}_{3}$ were then heated in air at $1300{ }^{\circ} \mathrm{C}$ for 4 periods of $48 \mathrm{~h}$. Samples of $\mathrm{La}_{0.5} \mathrm{Sr}_{0.5} \mathrm{Fe}_{0.5} \mathrm{Rh}_{0.5} \mathrm{O}_{3}$ were heated under flowing oxygen at $1300{ }^{\circ} \mathrm{C}$ for 3 periods of $48 \mathrm{~h}$. All samples were reground and pressed into pellets between heating periods.

\section{Characterization}

X-ray powder diffraction data were collected using a PANalytical X'pert diffractometer incorporating an X'celerator position-sensitive detector (monochromatic $\mathrm{Cu} \mathrm{K} \alpha_{1}$ radiation). High-resolution synchrotron X-ray powder diffraction data (SXRD) were collected using the I11 instrument at the Diamond Light Source Ltd. Diffraction patterns were collected using Si-calibrated X-rays with an approximate wavelength of $0.825 \AA$ from samples sealed in $0.3 \mathrm{~mm}$ diameter borosilicate glass capillaries. Rietveld refinements were performed using the GSAS suite of programs. ${ }^{20}$ Magnetization data were collected using a Quantum Design MPMS SQUID magnetometer. Four-probe resistivity measurements were performed using a home-made apparatus on bars cut from sintered pellets. ${ }^{57} \mathrm{Fe}$ Mössbauer spectroscopy measurements utilized acrylic absorber discs with a sample area of $1.767 \mathrm{~cm}^{2}$ which were loaded to present $2.16 \times 10^{-3} \mathrm{~g} \mathrm{~cm}^{-2}$ of $\mathrm{Fe}$, and achieve a Mössbauer thickness of 1 . Samples were homogeneously mixed with graphite to achieve this level of loading. The $14.4 \mathrm{keV} \gamma$-rays were supplied by the cascade decay of $25 \mathrm{mCi}{ }^{57} \mathrm{Co}$ in a $\mathrm{Rh}$ matrix source, oscillated at constant acceleration by a SeeCo W304 drive unit, and detected using a SeeCo $45431 \mathrm{Kr}$ proportional counter operating with $1.745 \mathrm{kV}$ bias voltage applied to the cathode. All measurements were calibrated relative to $\alpha$-Fe foil. Spectral data were fitted using the Recoil software package, ${ }^{21}$ using Lorentzian line shapes.

X-ray photoelectron spectroscopy (XPS) analysis was performed using a Kratos Axis SUPRA XPS fitted with a monochromated Al $\mathrm{K}_{\alpha} \mathrm{X}$-ray source $(1486.7 \mathrm{eV})$, a spherical sector analyser and 3 multichannel resistive plate, 128 channel delay line detectors. All data was recorded at $150 \mathrm{~W}$ and a spot size of
$700 \times 300 \mu \mathrm{m}$. Survey scans were recorded at a pass energy of $160 \mathrm{eV}$, and high-resolution scans recorded at a pass energy of $20 \mathrm{eV}$. Electronic charge neutralization was achieved using a magnetic immersion lens. Filament current $=0.27 \mathrm{~A}$, charge balance $=3.3 \mathrm{~V}$, filament bias $=3.8 \mathrm{~V}$. All sample data was recorded at a pressure below $10^{-8}$ Torr and a room temperature of 294 K. Data was analysed using CasaXPS v2.3.18PR1.0. C $1 \mathrm{~s} \mathrm{sp}^{3}$ peaks were calibrated to $284.8 \mathrm{eV}$.

\section{Results}

\section{Structural characterisation of $\mathrm{La}_{0.5} \mathrm{Sr}_{0.5} \mathrm{Mn}_{0.5} \mathrm{Rh}_{0.5} \mathrm{O}_{3}$}

SXRD data collected from $\mathrm{La}_{0.5} \mathrm{Sr}_{0.5} \mathrm{Mn}_{0.5} \mathrm{Rh}_{0.5} \mathrm{O}_{3}$ at room temperature could be readily indexed using an orthorhombic unit cell ( $a=5.483 \AA$, $b=7.776 \AA$, $5.536 \AA$ ) with extinction conditions consistent with the Pnma (\# 62) space group. A structural model was constructed based on the reported structure of $\mathrm{LaMn}_{0.5} \mathrm{Rh}_{0.5} \mathrm{O}_{3},{ }^{15}$ but with the $\mathrm{La}^{3+}$ replaced by a $1: 1$ ratio of $\mathrm{La}^{3+}: \mathrm{Sr}^{2+}$. This model was refined against the SXRD data to achieve a good fit as shown in Fig. 1 and detailed in Table 1, with selected bond lengths listed in Table 2. SXRD data provide no evidence for $\mathrm{Mn} / \mathrm{Rh}$ cation-order, with a model based on the reported cation-ordered structure of $\mathrm{LaSrNiRuO}_{6}$ (space group $\left.P 2_{1} / n\right)^{11}$ reverting to a disordered structure when the $\mathrm{Mn}$ and $\mathrm{Rh}$ occupancies were refined.

\section{Structural and chemical characterisation of \\ $\mathrm{La}_{0.5} \mathrm{Sr}_{0.5} \mathrm{Fe}_{0.5} \mathrm{Rh}_{0.5} \mathrm{O}_{3}$}

SXRD data collected from $\mathrm{La}_{0.5} \mathrm{Sr}_{0.5} \mathrm{Fe}_{0.5} \mathrm{Rh}_{0.5} \mathrm{O}_{3}$ at room temperature could be readily indexed using an orthorhombic unit cell ( $a=5.525 \AA, b=7.860 \AA$ А $5.563 \AA$,) with extinction conditions consistent with the Pnma (\# 62) space group. A structural model was constructed, based that used for $\mathrm{La}_{0.5} \mathrm{Sr}_{0.5} \mathrm{Mn}_{0.5} \mathrm{Rh}_{0.5} \mathrm{O}_{3}$, and refined against the SXRD data to achieve a good fit as shown in Fig. 2 and detailed in Table 3, with selected bond lengths listed in Table 4. SXRD data

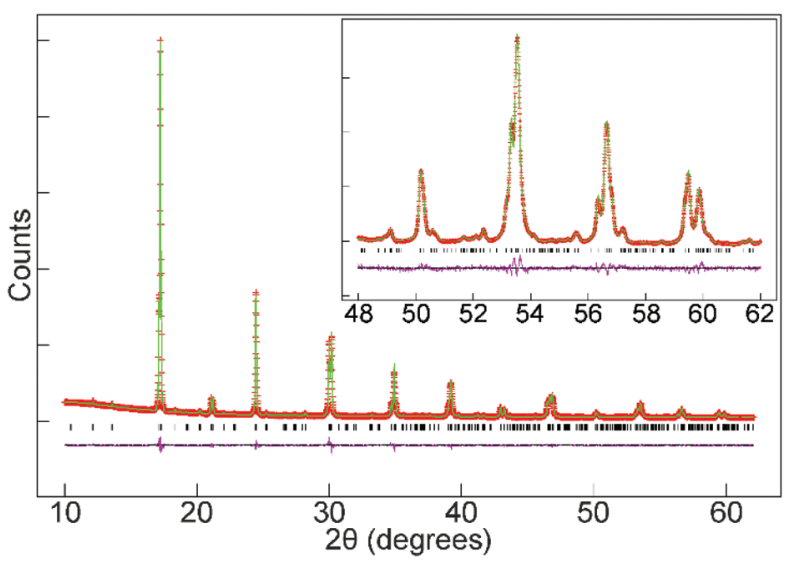

Fig. 1 Observed, calculated and difference plots from the structural refinement of $\mathrm{La}_{0.5} \mathrm{Sr}_{0.5} \mathrm{Mn}_{0.5} \mathrm{Rh}_{0.5} \mathrm{O}_{3}$ against SXRD data collected at room temperature. Inset shows quality of fit at large values of $2 \theta$. 
Table 1 Parameters from the structural refinement of $\mathrm{La}_{0.5} \mathrm{Sr}_{0.5} \mathrm{Mn}_{0.5} \mathrm{Rh}_{0.5} \mathrm{O}_{3}$ against synchrotron $\mathrm{X}$-ray powder diffraction data

\begin{tabular}{llllll}
\hline Atom & $x$ & $y$ & $z$ & Occupancy & $U_{\text {iso }}\left(\AA^{2}\right)$ \\
\hline $\mathrm{La} / \mathrm{Sr}$ & $0.5181(1)$ & $\frac{1}{4}$ & $0.0023(1)$ & $0.5 / 0.5$ & $0.009(1)$ \\
$\mathrm{Mn} / \mathrm{Rh}$ & 0 & 0 & 0 & $0.5 / 0.5$ & $0.004(1)$ \\
$\mathrm{O}(1)$ & $0.0000(6)$ & $\frac{1}{4}$ & $0.9434(6)$ & 1 & $0.009(1)$ \\
$\mathrm{O}(2)$ & $0.2701(8)$ & $0.0305(4)$ & $0.2189(6)$ & 1 & $0.020(1)$
\end{tabular}

$\mathrm{La}_{0.5} \mathrm{Sr}_{0.5} \mathrm{Mn}_{0.5} \mathrm{Rh}_{0.5} \mathrm{O}_{3}$ space group Pnma (\#62). $a=5.4830(1) \AA ⿻$

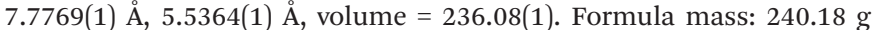
$\mathrm{mol}^{-1}, Z=4$. Radiation source: Synchrotron X-ray, $\lambda=0.82622 \AA . \chi^{2}=$ $19.75 ; \mathrm{w} R_{\mathrm{p}}=2.92 \% ; R_{\mathrm{p}}=1.88 \%$.

Table 2 Selected bond lengths from the structure of $\mathrm{La}_{0.5} \mathrm{Sr}_{0.5} \mathrm{Mn}_{0.5} \mathrm{Rh}_{0.5} \mathrm{O}_{3}$

\begin{tabular}{lll}
\hline Cation & Anion & Bond length $(\AA)$ \\
\hline $\mathrm{Mn} / \mathrm{Rh}$ & $\mathrm{O}(1) \times 2$ & $1.969(1)$ \\
& $\mathrm{O}(2) \times 2$ & $1.928(4)$ \\
& $\mathrm{O}(2) \times 2$ & $2.017(4)$ \\
$\mathrm{La} / \mathrm{Sr}$ & $\mathrm{O}(1)$ & $2.470(3)$ \\
& $\mathrm{O}(1)$ & $2.662(3)$ \\
$\mathrm{O}(1)$ & $2.859(3)$ \\
$\mathrm{O}(1)$ & $3.070(3)$ \\
$\mathrm{O}(2) \times 2$ & $2.490(4)$ \\
$\mathrm{O}(2) \times 2$ & $2.684(4)$ \\
& $\mathrm{O}(2) \times 2$ & $2.758(3)$ \\
& $\mathrm{O}(2) \times 2$ & $3.117(4)$
\end{tabular}

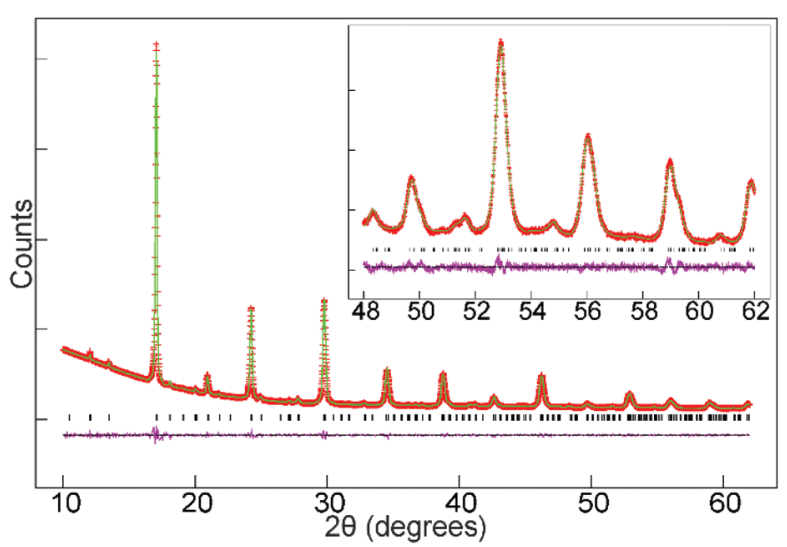

Fig. 2 Observed, calculated and difference plots from the structural refinement of $\mathrm{La}_{0.5} \mathrm{Sr}_{0.5} \mathrm{Fe}_{0.5} \mathrm{Rh}_{0.5} \mathrm{O}_{3}$ against SXRD data collected at room temperature. Inset shows quality of fit at large values of $2 \theta$.

provide no evidence for $\mathrm{Fe} / \mathrm{Rh}$ cation-order, with a model based on the reported cation-ordered structure of $\mathrm{LaSrNiRuO}_{6}$ (space group $\left.P 2_{1} / n\right)^{11}$ reverting to a disordered structure when the Fe and Rh occupancies were refined.

${ }^{57} \mathrm{Fe}$ Mössbauer analysis of $\mathrm{La}_{0.5} \mathrm{Sr}_{0.5} \mathrm{Fe}_{0.5} \mathrm{Rh}_{0.5} \mathrm{O}_{3}$

A ${ }^{57}$ Fe Mössbauer spectrum collected from $\mathrm{La}_{0.5} \mathrm{Sr}_{0.5} \mathrm{Fe}_{0.5} \mathrm{Rh}_{0.5} \mathrm{O}_{3}$ at room temperature can be satisfactorily fitted by two doublets as shown in Fig. 3 and detailed in Table 5.
Table 3 Parameters from the structural refinement of $\mathrm{La}_{0.5} \mathrm{Sr}_{0.5} \mathrm{Fe}_{0.5} \mathrm{Rh}_{0.5} \mathrm{O}_{3}$ against synchrotron $\mathrm{X}$-ray powder diffraction data

\begin{tabular}{llllll}
\hline Atom & $x$ & $y$ & $z$ & Occupancy & $U_{\text {iso }}\left(\AA^{2}\right)$ \\
\hline $\mathrm{La} / \mathrm{Sr}$ & $0.5138(3)$ & $\frac{1}{4}$ & $0.0012(6)$ & $0.5 / 0.5$ & $0.007(1)$ \\
$\mathrm{Fe} / \mathrm{Rh}$ & 0 & 0 & 0 & $0.5 / 0.5$ & $0.003(1)$ \\
$\mathrm{O}(1)$ & $0.9982(5)$ & $\frac{1}{4}$ & $0.0369(4)$ & 1 & $0.009(1)$ \\
$\mathrm{O}(2)$ & $0.2294(3)$ & $0.9594(1)$ & $0.2800(2)$ & 1 & $0.016(1)$
\end{tabular}

$\mathrm{La}_{0.5} \mathrm{Sr}_{0.5} \mathrm{Fe}_{0.5} \mathrm{Rh}_{0.5} \mathrm{O}_{3}$ space group Pnma (\#62). $a=5.5254(3) \AA, \quad b=$ 7.8602(5) А̊, 5.5635(4) A, volume $=241.63(3)$. Formula mass: $240.63 \mathrm{~g}$ $\mathrm{mol}^{-1}, Z=4$. Radiation source: Synchrotron X-ray, $\lambda=0.8259 \AA . \chi^{2}=$ $15.85 ; \mathrm{w} R_{\mathrm{p}}=2.41 \% ; R_{\mathrm{p}}=1.54 \%$.

Table 4 Selected bond lengths from the structure of $\mathrm{La}_{0.5} \mathrm{Sr}_{0.5} \mathrm{Fe}_{0.5} \mathrm{Rh}_{0.5} \mathrm{O}_{3}$

\begin{tabular}{lll}
\hline Cation & Anion & Bond $(\AA)$ \\
\hline $\mathrm{Fe} / \mathrm{Rh}$ & $\mathrm{O}(1) \times 2$ & $1.976(1)$ \\
& $\mathrm{O}(2) \times 2$ & $1.958(1)$ \\
& $\mathrm{O}(2) \times 2$ & $2.033(1)$ \\
$\mathrm{La} / \mathrm{Sr}$ & $\mathrm{O}(1)$ & $2.571(4)$ \\
& $\mathrm{O}(1)$ & $2.684(3)$ \\
& $\mathrm{O}(1)$ & $2.856(3)$ \\
& $\mathrm{O}(1)$ & $2.995(4)$ \\
& $\mathrm{O}(2) \times 2$ & $2.456(2)$ \\
& $\mathrm{O}(2) \times 2$ & $2.678(2)$ \\
& $\mathrm{O}(2) \times 2$ & $2.849(2)$ \\
& $\mathrm{O}(2) \times 2$ & $3.176(2)$
\end{tabular}

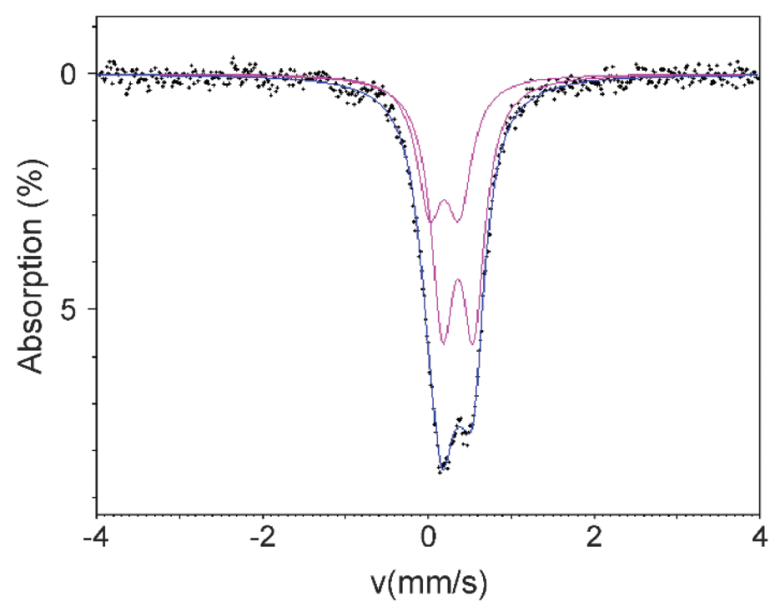

Fig. $3{ }^{57} \mathrm{Fe}$ Mössbauer spectrum collected from $\mathrm{La}_{0.5} \mathrm{Sr}_{0.5} \mathrm{Fe}_{0.5} \mathrm{Rh}_{0.5} \mathrm{O}_{3}$ at room temperature.

Table 5 Parameters extracted from fit to ${ }^{57} \mathrm{Fe}$ Mössbauer spectrum collected from $\mathrm{La}_{0.5} \mathrm{Sr}_{0.5} \mathrm{Fe}_{0.5} \mathrm{Rh}_{0.5} \mathrm{O}_{3}\left(\chi^{2}=0.650\right)$

\begin{tabular}{lllll}
\hline Doublet & $\begin{array}{l}C_{\mathrm{S}} \\
\left(\mathrm{mm} \mathrm{s}^{-1}\right)\end{array}$ & $\begin{array}{l}\Delta \\
\left(\mathrm{mm} \mathrm{s}^{-1}\right)\end{array}$ & $\begin{array}{l}\text { HWHM } \\
\left(\mathrm{mm} \mathrm{s}^{-1}\right)\end{array}$ & $\begin{array}{l}\text { Site population } \\
(\%)\end{array}$ \\
\hline 1 & $0.361(18)$ & $0.371(6)$ & $0.166(16)$ & $63(19)$ \\
2 & $0.195(42)$ & $0.355(14)$ & $0.184(24)$ & $37(19)$
\end{tabular}


We attribute the need to use two doublets to obtain a satisfactory fit to the $\mathrm{Fe} / \mathrm{Rh}$ cation-disordered structure of $\mathrm{La}_{0.5} \mathrm{Sr}_{0.5} \mathrm{Fe}_{0.5} \mathrm{Rh}_{0.5} \mathrm{O}_{3}$. Each octahedral transition-metal coordination site in the perovskite framework is surrounded by 6 others. In a disordered $\mathrm{Fe} / \mathrm{Rh}$ array the majority of the iron cations with have 3 iron neighbours and 3 rhodium neighbours. However there will be a significant number which have $\mathrm{Fe}_{2} \mathrm{Rh}_{4}$ or $\mathrm{Fe}_{4} \mathrm{Rh}_{2}$ surrounding them and a smaller number with $\mathrm{Fe}_{1} \mathrm{Rh}_{5}$ or $\mathrm{Fe}_{5} \mathrm{Rh}_{1}$. When we also consider that the $\mathrm{Fe}_{3} \mathrm{Rh}_{3}$ environments can be arranged as either fac or mer, and the $\mathrm{Fe}_{2} \mathrm{Rh}_{4}$ and $\mathrm{Fe}_{4} \mathrm{Rh}_{2}$ as cis or trans, it can be seen that there are a large number of local environments for the iron cations within the disordered $\mathrm{Rh} / \mathrm{Fe}$ array, each with a different Mössbauer chemical shift and doublet splitting. It is not possible to resolve this large number of components from the data in a meaningful way, so we have utilized a 2-doublet fit to extract the range of $C_{\mathrm{s}}$ and $\Delta$ values spanned by the different Fe local coordination environments. Comparison with literature standards indicates these signals correspond to octahedrally coordinated $\mathrm{Fe}^{3+} \cdot 22,23$

To investigate the possibility that some $\mathrm{Fe}^{4+}$ cations are present in $\mathrm{La}_{0.5} \mathrm{Sr}_{0.5} \mathrm{Fe}_{0.5} \mathrm{Rh}_{0.5} \mathrm{O}_{3}$ we have performed a further fit in which one doublet was fixed at $C_{\mathrm{S}}=0$, corresponding to $\mathrm{Fe}^{4+}$. This approach also gives a reasonable fit to the data and indicates a maximum concentration of $12(2) \% \mathrm{Fe}^{4+}$ as described in detail in the ESI. $\dagger$

\section{XPS analysis of $\mathrm{La}_{0.5} \mathrm{Sr}_{0.5} \mathrm{Mn}_{0.5} \mathrm{Rh}_{0.5} \mathrm{O}_{3}$ and}

$\mathrm{La}_{0.5} \mathrm{Sr}_{0.5} \mathrm{Fe}_{0.5} \mathrm{Rh}_{0.5} \mathrm{O}_{3}$

A Rh 3d spectrum collected from $\mathrm{La}_{0.5} \mathrm{Sr}_{0.5} \mathrm{Fe}_{0.5} \mathrm{Rh}_{0.5} \mathrm{O}_{3}$ is shown in Fig. 4a and exhibits a well resolved $\mathrm{Rh} 3 \mathrm{~d}_{5 / 2}$ component centred at $\mathrm{BE}=308.9 \mathrm{eV}(\mathrm{FWHM}=1.86 \mathrm{eV})$ and $\mathrm{a} \mathrm{Rh}$ $3 \mathrm{~d}_{3 / 2}$ component centred at $\mathrm{BE}=313.7 \mathrm{eV}(\mathrm{FWHM}=2.63 \mathrm{eV})$. When combined with an O $1 \mathrm{~s}-\mathrm{Rh} 3 \mathrm{~d}_{5 / 2}$ separation of $219.6 \mathrm{eV}$, as shown in Fig. 4a, these values indicate an oxidation state of $\mathrm{Rh}^{4+} \cdot{ }^{24,25}$ Fe 2 p spectra (Fig. S2, ESI $\dagger$ ) exhibit a well resolved Fe $2 \mathrm{p}_{3 / 2}$ component centred at $\mathrm{BE}=710.1 \mathrm{eV}(\mathrm{FWHM}=3.44 \mathrm{eV})$ and a Fe $2 \mathrm{p}_{1 / 2}$ component centred at $\mathrm{BE}=723.3 \mathrm{eV}(\mathrm{FWHM}=$ $4.65 \mathrm{eV}$ ), consistent with $\mathrm{Fe}^{3+} \cdot{ }^{26,27}$ These data, in combination with the ${ }^{57} \mathrm{Fe}$ Mössbauer data indicate an $\mathrm{Fe}^{3+} / \mathrm{Rh}^{4+}$ oxidation state combination for $\mathrm{La}_{0.5} \mathrm{Sr}_{0.5} \mathrm{Fe}_{0.5} \mathrm{Rh}_{0.5} \mathrm{O}_{3}$.

Similarly, a $\mathrm{Rh} 3 \mathrm{~d}$ spectrum collected from $\mathrm{La}_{0.5} \mathrm{Sr}_{0.5} \mathrm{Mn}_{0.5} \mathrm{Rh}_{0.5} \mathrm{O}_{3}$, shown in Fig. 4b, exhibits a well resolved $\mathrm{Rh} 3 \mathrm{~d}_{5 / 2}$ component centred at $\mathrm{BE}=308.7 \mathrm{eV}$ (FWHM $=1.45 \mathrm{eV}$ ), a $\mathrm{Rh} 3 \mathrm{~d}_{3 / 2}$ component centred at $\mathrm{BE}=313.4 \mathrm{eV}$ $($ FWHM $=2.16 \mathrm{eV})$ and a O $1 \mathrm{~s}-\mathrm{Rh} 3 \mathrm{~d}_{5 / 2}$ separation of $220.0 \mathrm{eV}$ which also indicate an oxidation state of $\mathrm{Rh}^{4+} \cdot{ }^{24,25} \mathrm{Mn} 2 \mathrm{p}$ spectra (Fig. S3, ESI $\dagger$ ) exhibit a well resolved Mn $2 \mathrm{p}_{3 / 2}$ component centred at $\mathrm{BE}=641.6 \mathrm{eV}(\mathrm{FWHM}=3.79 \mathrm{eV})$ and $\mathrm{an}$ $2 \mathrm{p}_{1 / 2}$ component centred at $\mathrm{BE}=652.9 \mathrm{eV}(\mathrm{FWHM}=4.35 \mathrm{eV})$, consistent with $\mathrm{Mn}^{3+} \cdot 26,28$ These data indicate an $\mathrm{Mn}^{3+} / \mathrm{Rh}^{4+}$ oxidation state combination for $\mathrm{La}_{0.5} \mathrm{Sr}_{0.5} \mathrm{Mn}_{0.5} \mathrm{Rh}_{0.5} \mathrm{O}_{3}$.

Magnetic characterisation of $\mathrm{La}_{0.5} \mathrm{Sr}_{0.5} \mathrm{Mn}_{0.5} \mathrm{Rh}_{0.5} \mathrm{O}_{3}$

Zero-field cooled (ZFC) and field cooled (FC) magnetization data collected from $\mathrm{La}_{0.5} \mathrm{Sr}_{0.5} \mathrm{Mn}_{0.5} \mathrm{Rh}_{0.5} \mathrm{O}_{3}$ in an applied field
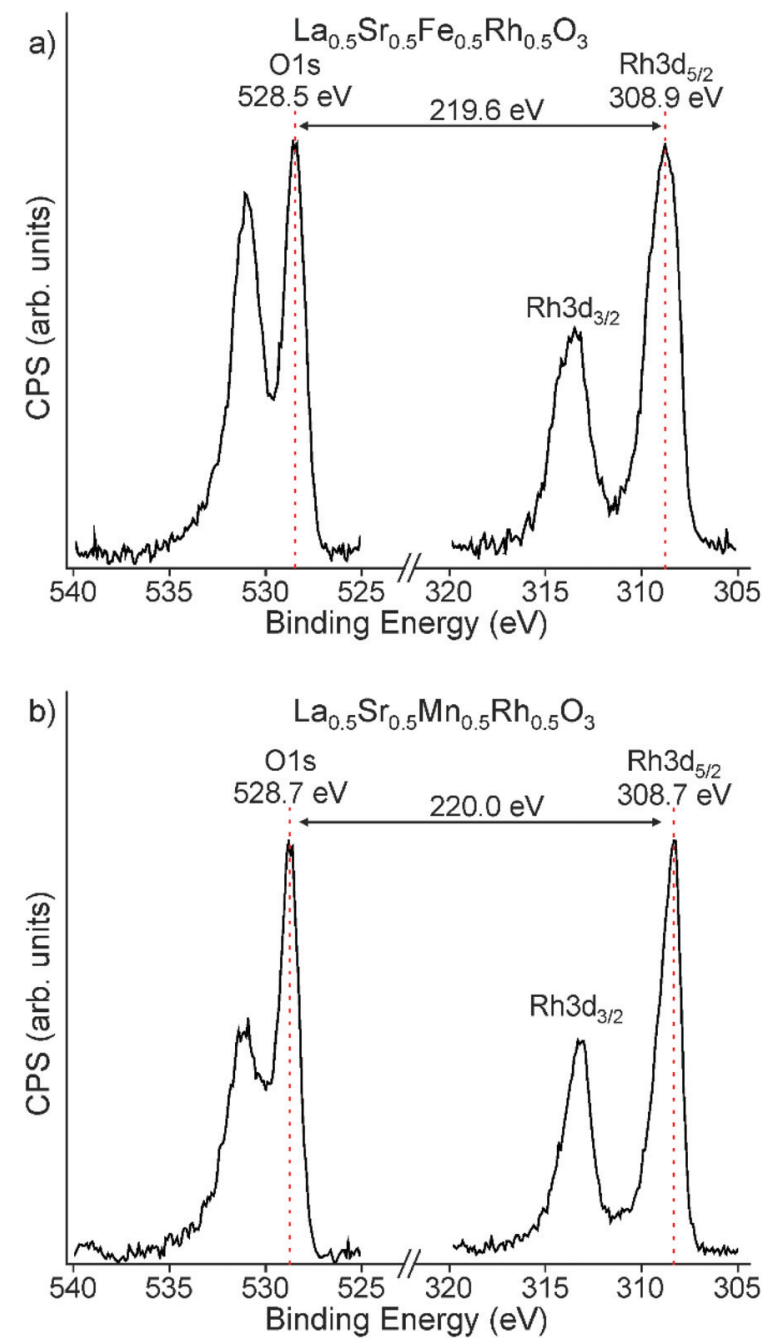

Fig. 4 Binding energy separation between $\mathrm{O}$ 1s and $\mathrm{Rh} 3 \mathrm{~d}$ peaks of (a) $\mathrm{LaSrFe}_{0.5} \mathrm{Rh}_{0.5} \mathrm{O}_{3}$ and (b) $\mathrm{LaSrFe}_{0.5} \mathrm{Rh}_{0.5} \mathrm{O}_{3}$ which is consistent with the presence of $\mathrm{Rh}^{4+}$ in both cases.

of 100 Oe (Fig. 5) diverge weekly below $100 \mathrm{~K}$, before diverging more strongly below $60 \mathrm{~K}$, consistent with the onset of magnetic order. Data in the range $100<T / K<300$ do not obey the Curie-Weiss law. Magnetization-field data collected at $5 \mathrm{~K}$ are consistent with ferromagnetic behaviour with a coercive field of 190 Oe (as shown more clearly in Fig. S3 in the ESI $\dagger$ ) and a saturated moment of $1.43 \mu_{\mathrm{B}}$ per formula unit $\left(2.86 \mu_{\mathrm{B}}\right.$ per $\left.\mathrm{Mn}\right)$.

Temperature-dependent 4-probe transport measurements indicate that $\mathrm{La}_{0.5} \mathrm{Sr}_{0.5} \mathrm{Mn}_{0.5} \mathrm{Rh}_{0.5} \mathrm{O}_{3}$ is highly resistive, with a semiconducting/insulating temperature dependence $(\delta \rho / \delta T<$ 0 ) as shown in Fig. 6. A plot of $\ln \rho$ against $T^{-1 / 4}$ is linear in the range $90<T / K<300$ consistent with $3 \mathrm{D}$ variable range hopping.

\section{Magnetic characterisation of $\mathrm{La}_{0.5} \mathrm{Sr}_{0.5} \mathrm{Fe}_{0.5} \mathrm{Rh}_{0.5} \mathrm{O}_{3}$}

ZFC and FC data collected from $\mathrm{La}_{0.5} \mathrm{Sr}_{0.5} \mathrm{Fe}_{0.5} \mathrm{Rh}_{0.5} \mathrm{O}_{3}$ (Fig. 7) can be fit by the Curie-Weiss law $(\chi=C /(T-\theta)+K)$ in the temperature range $60<T / K<300$ to yield value of $C=1.132(1)$ 


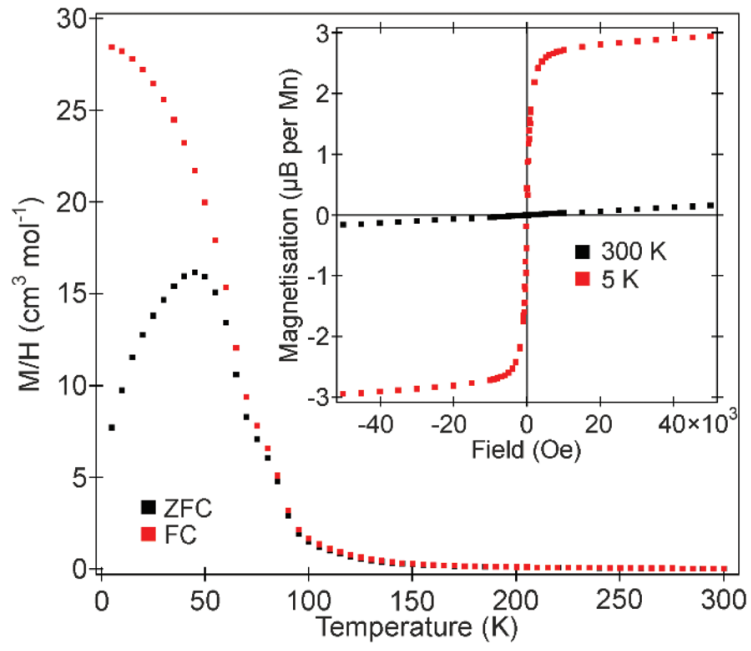

Fig. 5 ZFC and FC magnetisation data collected from $\mathrm{La}_{0.5} \mathrm{Sr}_{0.5} \mathrm{Mn}_{0.5} \mathrm{Rh}_{0.5} \mathrm{O}_{3}$ in an applied field of $100 \mathrm{Oe}$. Inset shows magnetisation-field isotherms collected at $300 \mathrm{~K}$ and $5 \mathrm{~K}$.

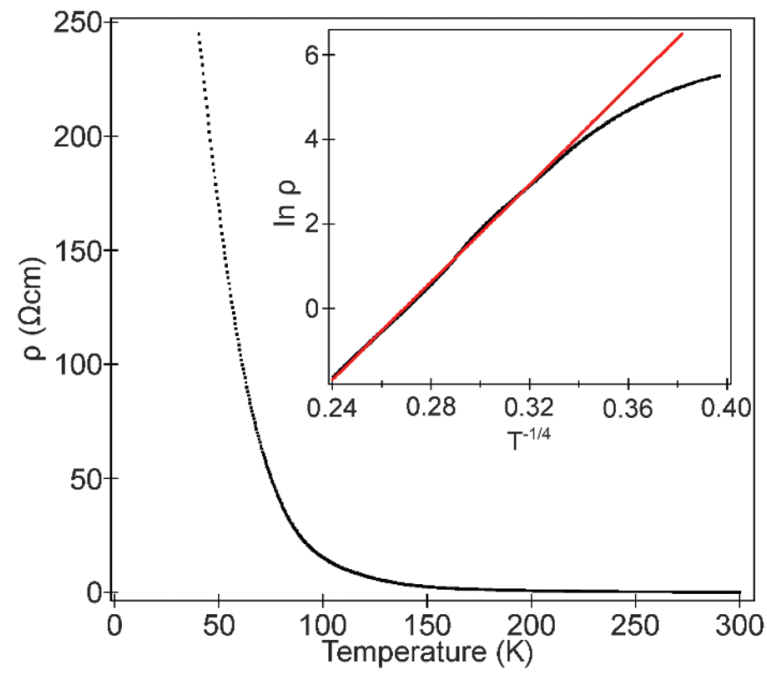

Fig. 6 Temperature-dependent resistivity of $\mathrm{La}_{0.5} \mathrm{Sr}_{0.5} \mathrm{Mn}_{0.5} \mathrm{Rh}_{0.5} \mathrm{O}_{3}$. Inset shows fit to 3D variable-range hopping model.

$\mathrm{cm}^{3} \mathrm{~K} \mathrm{~mol}^{-1}, \theta=-30.9 \mathrm{~K}, K=7.75(7) \times 10^{-4} \mathrm{~cm}^{3} \mathrm{~mol}^{-1}$, as shown in Fig. 6. For $T<45 \mathrm{~K}$ the ZFC and FC data diverge, indicative of a magnetic phase transition. Magnetization data collected at $300 \mathrm{~K}$ exhibit a linear field dependence. In contrast, magnetization data collected at $5 \mathrm{~K}$ after cooling from $300 \mathrm{~K}$ in an applied field of 50000 Oe exhibit hysteresis and are displaced from the origin, indicative of spin-glass behaviour.

Temperature-dependent 4-probe transport measurements indicate that $\mathrm{La}_{0.5} \mathrm{Sr}_{0.5} \mathrm{Fe}_{0.5} \mathrm{Rh}_{0.5} \mathrm{O}_{3}$ is highly resistive, with a semiconducting/insulating temperature dependence $(\delta \rho / \delta T<$ 0 ) as shown in Fig. 8. A plot of $\ln \rho$ against $T^{-1 / 4}$ is linear in the range $50<T / K<300$ consistent with $3 \mathrm{D}$ variable range hopping.
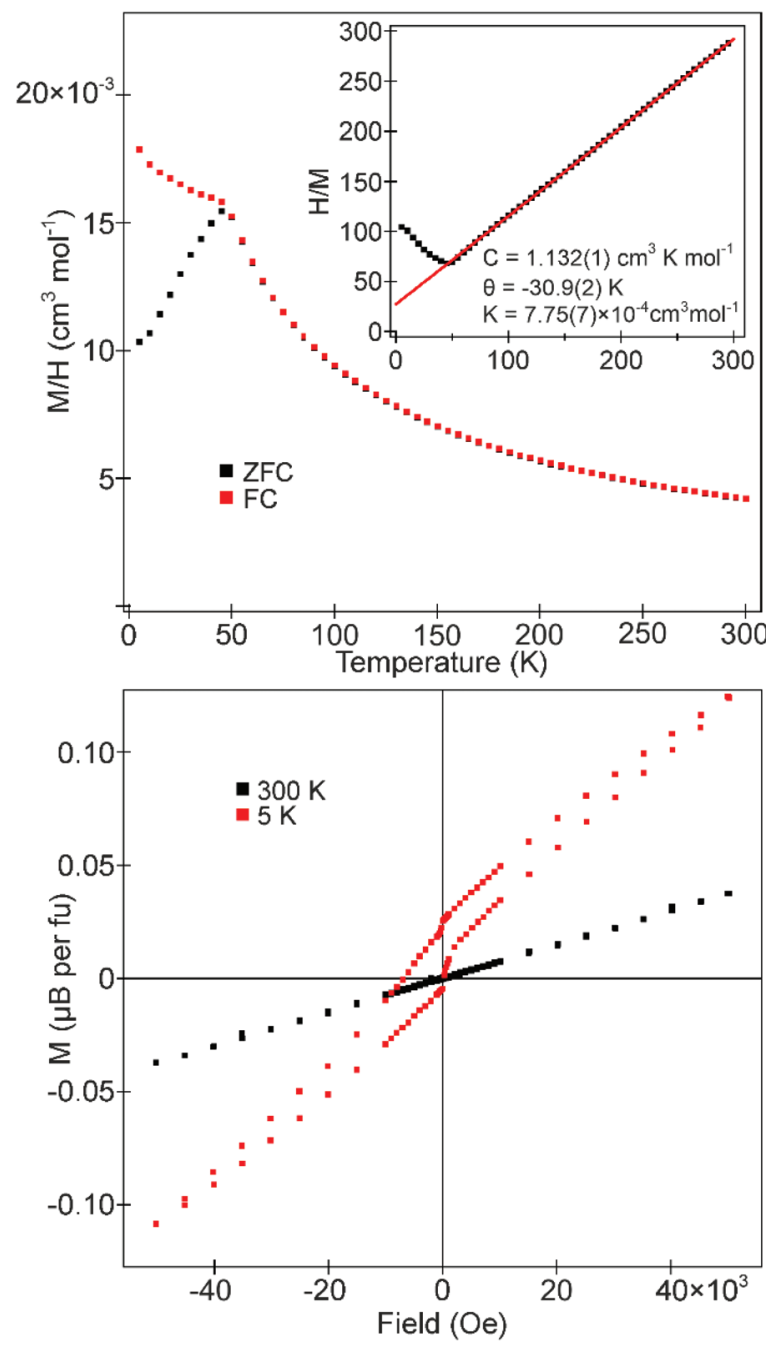

Fig. 7 (Top) ZFC and FC magnetisation data collected from $\mathrm{La}_{0.5} \mathrm{Sr}_{0.5} \mathrm{Fe}_{0.5} \mathrm{Rh}_{0.5} \mathrm{O}_{3}$ in an applied field of $100 \mathrm{Oe}$. Inset shows CurieWeiss law fit to the ZFC data. (Bottom) Magnetisation-field isotherms collected from $\mathrm{La}_{0.5} \mathrm{Sr}_{0.5} \mathrm{Fe}_{0.5} \mathrm{Rh}_{0.5} \mathrm{O}_{3}$ at $300 \mathrm{~K}$ and at $5 \mathrm{~K}$ after field cooling from $300 \mathrm{~K}$ in an applied filed of $50000 \mathrm{Oe}$.

\section{Discussion}

SXRD data indicate that in common with other reported $\mathrm{La}_{1-x} \mathrm{Sr}_{x} \mathrm{Mn}_{0.5} \mathrm{Rh}_{0.5} \mathrm{O}_{3} \quad$ phases, ${ }^{15,29} \quad \mathrm{La}_{0.5} \mathrm{Sr}_{0.5} \mathrm{Mn}_{0.5} \mathrm{Rh}_{0.5} \mathrm{O}_{3}$ adopts a cation-disordered, $\mathrm{a}^{-} \mathrm{a}^{-} \mathrm{c}^{+}$distorted, $\mathrm{GdFeO}_{3}$-type perovskite structure. Comparison with the reported structures of $\mathrm{LaMn}_{0.5} \mathrm{Rh}_{0.5} \mathrm{O}_{3}$ and $\mathrm{La}_{0.75} \mathrm{Sr}_{0.25} \mathrm{Mn}_{0.5} \mathrm{Rh}_{0.5} \mathrm{O}_{3}$ reveals that both the unit cell volumes $\left(V=243.92 \AA^{3}, 240.01 \AA^{3}\right.$ and $236.08 \AA^{3}$ for $x=0,0.25$ and 0.5 respectively) and average ( $\mathrm{Mn} / \mathrm{Rh})-\mathrm{O}$ bond lengths $((\mathrm{Mn} / \mathrm{Rh})-\mathrm{O}=2.019 \AA, 1.995 \AA$ and $1.971 \AA$ for $x$ $=0,0.25$ and 0.5 respectively) decrease on substitution of $\mathrm{La}^{3+}$ by $\mathrm{Sr}^{2+}$, consistent with oxidation of the transition metal cations. In addition it should be noted that there is no evidence of an ordered Jahn-Teller distortion (long-range orbital order) of the $(\mathrm{Mn} / \mathrm{Rh}) \mathrm{O}_{6}$ octahedra in $\mathrm{La}_{0.5} \mathrm{Sr}_{0.5} \mathrm{Mn}_{0.5} \mathrm{Rh}_{0.5} \mathrm{O}_{3}$ (Table 2) or any other $\mathrm{La}_{1-x} \mathrm{Sr}_{x} \mathrm{Mn}_{0.5} \mathrm{Rh}_{0.5} \mathrm{O}_{3}$ phases (despite 


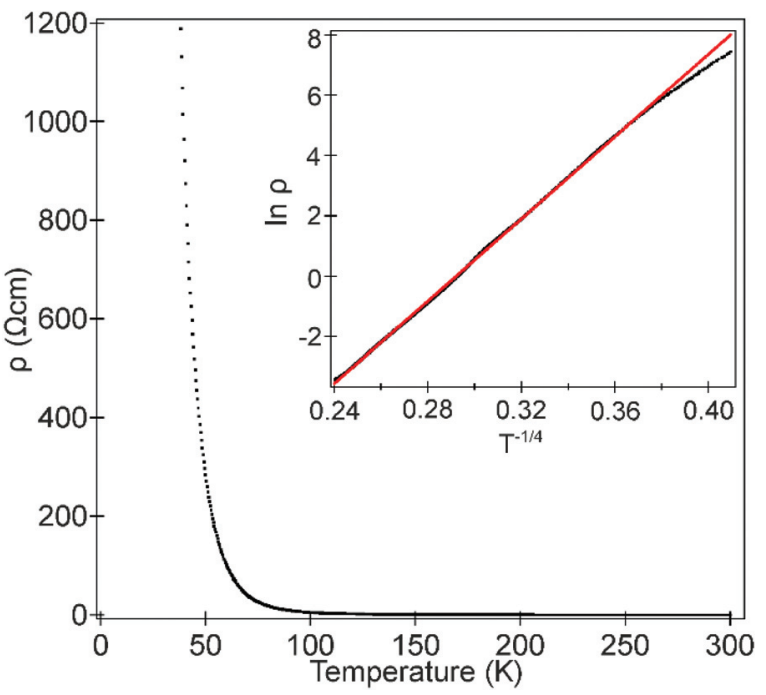

Fig. 8 Temperature-dependent resistivity of $\mathrm{La}_{0.5} \mathrm{Sr}_{0.5} \mathrm{Fe}_{0.5} \mathrm{Rh}_{0.5} \mathrm{O}_{3}$. Inset shows fit to 3D variable-range hopping model.

the unambiguous presence of $\mathrm{Mn}^{3+}$ in $\left.\mathrm{LaMn}_{0.5} \mathrm{Rh}_{0.5} \mathrm{O}_{3}\right)^{15}$ which is attributed to suppression by the disordered arrangement of the $\mathrm{Mn}$ and $\mathrm{Rh}$ cations.

$\mathrm{La}_{0.5} \mathrm{Sr}_{0.5} \mathrm{Fe}_{0.5} \mathrm{Rh}_{0.5} \mathrm{O}_{3}$ also adopts a cation-disordered, $\mathrm{a}^{-} \mathrm{a}^{-} \mathrm{c}^{+}$distorted, $\mathrm{GdFeO}_{3}$-type perovskite structure. Comparison with the reported structure of $\mathrm{LaFe}_{0.5} \mathrm{Rh}_{0.5} \mathrm{O}_{3}{ }^{13}$ again reveals that substitution of $\mathrm{La}^{3+}$ with $\mathrm{Sr}^{2+}$ leads to a contraction in unit cell volume, consistent with oxidation of the transition metals.

XPS and ${ }^{57} \mathrm{Fe}$ Mössbauer data indicate the predominant oxidation state combinations of $\mathrm{La}_{0.5} \mathrm{Sr}_{0.5} \mathrm{Mn}_{0.5} \mathrm{Rh}_{0.5} \mathrm{O}_{3}$ and $\mathrm{La}_{0.5} \mathrm{Sr}_{0.5} \mathrm{Fe}_{0.5} \mathrm{Rh}_{0.5} \mathrm{O}_{3}$ are $\mathrm{Mn}^{3+} / \mathrm{Rh}^{4+}$ and $\mathrm{Fe}^{3+} / \mathrm{Rh}^{4+}$ respectively. This is unexpected considering the oxide chemistry of these transition metals. For example, $\mathrm{Mn}^{3+}$ is not particularly stable in perovskite oxides, as illustrated by the observation that $\mathrm{LaMnO}_{3}$ must be prepared under low oxygen partial pressures to avoid the formation of mixed-valent $\mathrm{Mn}^{3+/ 4+}$ ' $\mathrm{LaMnO}_{3+\delta}$ ' phases. ${ }^{30}$ In contrast the preparation of $\mathrm{Mn}^{4+}$ containing perovskite oxides, such as $\mathrm{SrMnO}_{3}$, can be readily achieved by heating in air. ${ }^{31}$ Rhodium shows the opposite trend with $\mathrm{Rh}^{3+}$ perovskites such as $\mathrm{LaRhO}_{3}$ being readily prepared in air, ${ }^{32}$ while $\mathrm{Rh}^{4+}$ perovskite oxides such as $\mathrm{SrRhO}_{3}$ require highpressure synthesis conditions. ${ }^{33}$ It is therefore surprising that combining the two 'more stable' perovskite phases $\mathrm{LaRhO}_{3}$ and $\mathrm{SrMnO}_{3}$ to form $\mathrm{La}_{0.5} \mathrm{Sr}_{0.5} \mathrm{Mn}_{0.5} \mathrm{Rh}_{0.5} \mathrm{O}_{3}$ leads to a change in oxidation states from a $\mathrm{Mn}^{4+} / \mathrm{Rh}^{3+}$ combination in the ternary phases to a $\mathrm{Mn}^{3+} / \mathrm{Rh}^{4+}$ in the quaternary product. $\mathrm{Rh}^{4+}$ has been observed in perovskite oxides prepared at ambient pressure when it is combined with either electronegative elements such as $\mathrm{Cu}\left(\mathrm{LaCu}_{0.5}{ }^{2+} \mathrm{Rh}_{0.5}{ }^{4+} \mathrm{O}_{3}\right)^{15}$ or elements which only exhibit a single divalent cation oxidation state $\left(\mathrm{LaZn}_{0.5}{ }^{2+} \mathrm{Rh}_{0.5}{ }^{4+} \mathrm{O}_{3}, \mathrm{LaMg}_{0.5}{ }^{2+} \mathrm{Rh}_{0.5}{ }^{4+} \mathrm{O}_{3}\right) .{ }^{34}$ However, the observation of $\mathrm{Rh}^{4+}$ in the presence of cations such as $\mathrm{Fe}^{3+}$ and $\mathrm{Mn}^{3+}$ which can be oxidized relatively easily is unexpected and suggests the $3 \mathrm{~d}$ and $4 \mathrm{~d}$ levels of $\mathrm{Mn} / \mathrm{Fe}$ and $\mathrm{Rh}$ respectively are of similar energy.

\section{Magnetic behaviour}

Transport and magnetization data indicate that $\mathrm{La}_{0.5} \mathrm{Sr}_{0.5} \mathrm{Mn}_{0.5} \mathrm{Rh}_{0.5} \mathrm{O}_{3}$ is an electrical insulator which undergoes a transition to a ferromagnetic state at $T_{\mathrm{c}} \sim 60 \mathrm{~K}$. This behaviour is very similar to that reported for other perovskite oxides containing disordered arrays of $\mathrm{Mn}^{3+}$ cations such as $\mathrm{LaMn}_{0.5} \mathrm{Rh}_{0.5} \mathrm{O}_{3}\left(T_{\mathrm{c}}=65 \mathrm{~K}\right)^{15,16}$ and $\mathrm{LaMn}_{0.5} \mathrm{Ga}_{0.5} \mathrm{O}_{3}\left(T_{\mathrm{c}}=70 \mathrm{~K}\right)$, with the observed saturated ferromagnetic moment of $\mathrm{La}_{0.5} \mathrm{Sr}_{0.5} \mathrm{Mn}_{0.5} \mathrm{Rh}_{0.5} \mathrm{O}_{3}\left(2.86 \mu_{\mathrm{B}}\right.$ per $\left.\mathrm{Mn}\right)$ also being similar to that observed for $\mathrm{LaMn}_{0.5} \mathrm{Ga}_{0.5} \mathrm{O}_{3}{ }^{35,36}$

The ferromagnetic behaviour of $\mathrm{LaMn}_{0.5} \mathrm{Ga}_{0.5} \mathrm{O}_{3}$ has been rationalized by observing that partial substitution of the $\mathrm{Mn}^{3+}$ cations in $\mathrm{LaMnO}_{3}$ by a non-Jahn-Teller ion (e.g. $\left.\mathrm{Ga}^{3+}\right)$ suppresses the static Jahn-Teller distortion (orbital ordering) of the $\mathrm{Mn}^{\mathrm{III}} \mathrm{O}_{6}$ units present in the unsubstituted phase. ${ }^{35,37}$ In the absence of a static Jahn-Teller distortion (long-range orbital order), local dynamic Jahn-Teller distortions predominate which make all the $\mathrm{Mn}-\mathrm{O}-\mathrm{Mn}$ exchange couplings ferromagnetic, thus explaining the ferromagnetic order observed for $\mathrm{LaMn}_{1-x} \mathrm{Ga}_{x} \mathrm{O}_{3}$ phases with $x>0.5 .^{35,37}$ This mechanism can also be invoked to explain the ferromagnetic behaviour of $\mathrm{LaMn}_{0.5} \mathrm{Rh}_{0.5} \mathrm{O}_{3}$ as it is observed that the substitution of diamagnetic, low-spin $\mathrm{d}^{6}, \mathrm{Rh}^{3+}$ into $\mathrm{LaMnO}_{3}$ suppresses the static Jahn-Teller distortion of the $\mathrm{Mn}^{\mathrm{III}} \mathrm{O}_{6}$ units in a manner directly analogous to $\mathrm{Ga}^{3+}$ substitution. ${ }^{15,38}$

We propose that this dynamic Jahn-Teller mechanism is also the origin of the ferromagnetic behaviour of $\mathrm{La}_{0.5} \mathrm{Sr}_{0.5} \mathrm{Mn}_{0.5} \mathrm{Rh}_{0.5} \mathrm{O}_{3}$, as the substitution of $\mathrm{Rh}^{4+}$ for $\mathrm{Mn}^{3+}$ suppresses the static Jahn-Teller distortion of the manganese centres, leading to ferromagnetic couplings between $\mathrm{Mn}^{3+}$ cations in this cation-disordered material. It may be expected that the presence of paramagnetic $\mathrm{Rh}^{4+}$ centres would perturb the ferromagnetic $\mathrm{Mn}-\mathrm{O}-\mathrm{Mn}$ couplings, however the observation that the Curie temperature of $\mathrm{La}_{0.5} \mathrm{Sr}_{0.5} \mathrm{Mn}_{0.5} \mathrm{Rh}_{0.5} \mathrm{O}_{3}\left(T_{\mathrm{c}}\right.$ $\sim 60 \mathrm{~K})$ is very similar to those of $\mathrm{LaMn}_{0.5} \mathrm{Rh}_{0.5} \mathrm{O}_{3}\left(T_{\mathrm{c}}=\right.$ $65 \mathrm{~K})^{15,16}$ and $\mathrm{LaMn}_{0.5} \mathrm{Ga}_{0.5} \mathrm{O}_{3}\left(T_{\mathrm{c}}=70 \mathrm{~K}\right)^{35,36}$ indicates any $\mathrm{Mn}-\mathrm{O}-\mathrm{Rh}$ couplings present are weak. It is not clear if the $\mathrm{Rh}$ spins contribute to the magnetically ordered state of $\mathrm{La}_{0.5} \mathrm{Sr}_{0.5} \mathrm{Mn}_{0.5} \mathrm{Rh}_{0.5} \mathrm{O}_{3}$.

Magnetization data collected from $\mathrm{La}_{0.5} \mathrm{Sr}_{0.5} \mathrm{Fe}_{0.5} \mathrm{Rh}_{0.5} \mathrm{O}_{3}$ in the temperature range $60<T / K<300$ exhibit the temperaturedependence of the Curie-Weiss Law (Fig. 6). However, the Curie constant extracted from these data $\left(C=1.132(1) \mathrm{cm}^{3} \mathrm{~K}\right.$ $\mathrm{mol}^{-1}$ ) is much smaller than expected for simple paramagnetic behaviour for either an $\mathrm{Fe}^{3+} / \mathrm{Rh}^{4+}\left(C_{\text {expected }}=2.375 \mathrm{~cm}^{3} \mathrm{~K}\right.$ $\left.\mathrm{mol}^{-1}\right)$ or an $\mathrm{Fe}^{4+} / \mathrm{Rh}^{3+}\left(C_{\text {expected }}=1.50 \mathrm{~cm}^{3} \mathrm{~K} \mathrm{~mol}^{-1}\right)$ oxidation state combination. This indicates that strong spin-spin interactions are present in this temperature range, which is consistent with the large temperature-independent susceptibility observed $\left(K=7.75(7) \times 10^{-4} \mathrm{~cm}^{3} \mathrm{~mol}^{-1}\right)$ which contributes $\sim 20 \%$ to the total susceptibility at $300 \mathrm{~K}$.

On cooling below $T=45 \mathrm{~K}, \mathrm{La}_{0.5} \mathrm{Sr}_{0.5} \mathrm{Fe}_{0.5} \mathrm{Rh}_{0.5} \mathrm{O}_{3}$ undergoes a transition to a spin-glass state. In order to adopt a spin-glass 
state a system must be crystallographically disordered, and subject to magnetic frustration. If we consider the nearestneighbour super exchange couplings in $\mathrm{La}_{0.5} \mathrm{Sr}_{0.5} \mathrm{Fe}_{0.5} \mathrm{Rh}_{0.5} \mathrm{O}_{3}$ we observe $\mathrm{Fe}^{\mathrm{III}}-\mathrm{O}-\mathrm{Fe}^{\mathrm{III}}$ should be strongly antiferromagnetic, $\mathrm{Rh}^{\mathrm{IV}}-\mathrm{O}-\mathrm{Rh}^{\mathrm{IV}}$ should also be antiferromagnetic, but only weakly, and $\mathrm{Fe}^{\mathrm{III}}-\mathrm{O}-\mathrm{Rh}^{\mathrm{IV}}$ should be ferromagnetic. ${ }^{8}$ If these are the only significant magnetic couplings, a disordered $\mathrm{Fe} /$ $\mathrm{Rh}$ array would not be subject to magnetic frustration, making the observed spin-glass behaviour of $\mathrm{La}_{0.5} \mathrm{Sr}_{0.5} \mathrm{Fe}_{0.5} \mathrm{Rh}_{0.5} \mathrm{O}_{3}$ a little puzzling.

Battle et al. considered the spin-glass states of $\mathrm{SrFe}_{0.5} \mathrm{Ru}_{0.5} \mathrm{O}_{3}$ and $\mathrm{Sr}_{2} \mathrm{Fe}_{0.5} \mathrm{Ru}_{0.5} \mathrm{O}_{4}$ which arise from disordered arrays of $\mathrm{Fe}^{3+}$ and $\mathrm{Ru}^{5+} \cdot{ }^{39,40}$ The nearest-neighbour super exchange couplings in $\mathrm{SrFe}_{0.5} \mathrm{Ru}_{0.5} \mathrm{O}_{3}$ and $\mathrm{Sr}_{2} \mathrm{Fe}_{0.5} \mathrm{Ru}_{0.5} \mathrm{O}_{4}$ are directly analogous to those in $\mathrm{La}_{0.5} \mathrm{Sr}_{0.5} \mathrm{Fe}_{0.5} \mathrm{Rh}_{0.5} \mathrm{O}_{3}: \mathrm{Fe}^{\mathrm{III}}-\mathrm{O}-$ $\mathrm{Fe}^{\mathrm{III}}$ is antiferromagnetic, $\mathrm{Ru}^{\mathrm{V}}-\mathrm{O}-\mathrm{Ru}^{\mathrm{V}}$ is antiferromagnetic and $\mathrm{Fe}^{\mathrm{III}}-\mathrm{O}-\mathrm{Ru}^{\mathrm{V}}$ is ferromagnetic.

Battle et al. concluded that the order of coupling strengths is $\mathrm{Fe}^{\mathrm{III}}-\mathrm{O}-\mathrm{Fe}^{\mathrm{III}}>\mathrm{Ru}^{\mathrm{V}}-\mathrm{O}-\mathrm{Ru}^{\mathrm{V}} \sim \mathrm{Fe}^{\mathrm{III}}-\mathrm{O}-\mathrm{Ru}^{\mathrm{V}} \sim \mathrm{Fe}^{\mathrm{III}}-\mathrm{O}-\mathrm{O}-\mathrm{Fe}^{\mathrm{III}}$ where this last term is the next-nearest-neighbour Fe-Fe coupling. In this situation, frustration arises because the ferromagnetic $\mathrm{Fe}^{\mathrm{III}}-\mathrm{O}-\mathrm{Ru}^{\mathrm{V}}$ couplings align next-nearest neighbour Fe spins ferromagnetically, but the $\mathrm{Fe}^{\mathrm{III}}-\mathrm{O}-\mathrm{O}-\mathrm{Fe}^{\mathrm{III}}$ super-super exchange coupling is antiferromagnetic and the two couplings have about the same strength. We propose that a similar frustration between nearest-neighbour $\mathrm{Fe}^{\mathrm{III}}-\mathrm{O}-\mathrm{Rh}^{\mathrm{IV}}$ and nextnearest-neighbour $\mathrm{Fe}^{\mathrm{III}}-\mathrm{O}-\mathrm{O}-\mathrm{Fe}^{\mathrm{III}}$ couplings is responsible for the spin-glass behaviour in $\mathrm{La}_{0.5} \mathrm{Sr}_{0.5} \mathrm{Fe}_{0.5} \mathrm{Rh}_{0.5} \mathrm{O}_{3}$.

It is interesting to note that the contrasting magnetic behaviour of $\mathrm{La}_{0.5} \mathrm{Sr}_{0.5} \mathrm{Mn}_{0.5} \mathrm{Rh}_{0.5} \mathrm{O}_{3}$ and $\mathrm{La}_{0.5} \mathrm{Sr}_{0.5} \mathrm{Fe}_{0.5} \mathrm{Rh}_{0.5} \mathrm{O}_{3}$ can be understood on the basis of the relative strengths of the different transition-metal couplings in the two systems - the dominance of $3 \mathrm{~d}-3 \mathrm{~d}$ couplings in $\mathrm{La}_{0.5} \mathrm{Sr}_{0.5} \mathrm{Mn}_{0.5} \mathrm{Rh}_{0.5} \mathrm{O}_{3}$ leading to ferromagnetism; the comparable strengths of $3 \mathrm{~d}-$ $3 \mathrm{~d}$, 3d-4d couplings in $\mathrm{La}_{0.5} \mathrm{Sr}_{0.5} \mathrm{Fe}_{0.5} \mathrm{Rh}_{0.5} \mathrm{O}_{3}$ resulting in spinglass behaviour.

\section{Conclusions}

Hole doping of the perovskite phases $\mathrm{LaMn}_{0.5} \mathrm{Rh}_{0.5} \mathrm{O}_{3}$ and $\mathrm{LaFe}_{0.5} \mathrm{Rh}_{0.5} \mathrm{O}_{3}$ leads to the oxidation of $\mathrm{Rh}^{3+}$ to $\mathrm{Rh}^{4+}$ in the resulting $\mathrm{La}_{0.5} \mathrm{Sr}_{0.5} \mathrm{Mn}_{0.5} \mathrm{Rh}_{0.5} \mathrm{O}_{3}$ and $\mathrm{La}_{0.5} \mathrm{Sr}_{0.5} \mathrm{Fe}_{0.5} \mathrm{Rh}_{0.5} \mathrm{O}_{3}$ compounds. The stabilization of $\mathrm{Rh}^{4+}$ in the presence of the readily oxidizable $\mathrm{Mn}^{3+}$ and $\mathrm{Fe}^{3+}$ cations suggests that the $3 \mathrm{~d}$ $\mathrm{Mn} / \mathrm{Fe}$ states and $4 \mathrm{~d} \mathrm{Rh}$ states are of similar energy, so that if the electronic bandwidth of the phases could be increased, by decreasing the magnitude of the octahedral tilting distortion for example, or the $3 \mathrm{~d}$ and $4 \mathrm{~d}$ cations could be ordered, correlated electronic behaviour is likely, in line with computational predictions for high-valent rhodium oxides. ${ }^{41}$

\section{Conflicts of interest}

There are no conflicts to declare.

\section{Acknowledgements}

Experiments at the Diamond Light Source were performed as part of the Block Allocation Group award "Oxford Solid State Chemistry BAG to probe composition-structure-property relationships in solids" (EE13284). NH acknowledges funding from the "State Programme on Education of Azerbaijani Youth Abroad in 2007-2015" by the Ministry of Education of Azerbaijan. The XPS data collection was performed at the EPSRC National Facility for XPS ("HarwellXPS"), operated by Cardiff University and UCL, under Contract No. PR16195.

\section{Notes and references}

1 R. J. D. Tilley, Perovskites: Structure-Property Relationships, John Wiley and Sons, Chichester, 2016.

2 J. B. Goodenough and J.-S. Zhou, Chem. Mater., 1998, 10, 2980-2993.

3 T. Saha-Dasgupta, Mater. Res. Express, 2020, 7, 014003.

4 A. Halder, P. Sanyal and T. Saha-Dasgupta, Phys. Rev. B, 2019, 99, 020402(R).

5 K. L. Kobayashi, T. Kimura, H. Sawada, K. Terakura and Y. Tokura, Nature, 1998, 395, 677-680.

6 K. I. Kobayashi, T. Kimura, Y. Tomioka, H. Sawada, K. Terakura and Y. Tokura, Phys. Rev. B: Condens. Matter Mater. Phys., 1999, 59, 11159-11162.

7 H. Kato, T. Okuda, Y. Okimoto, Y. Tomioka, Y. Takenoya, A. Ohkubo, M. Kawasaki and Y. Tokura, Appl. Phys. Lett., 2002, 81, 328-330.

$8 \mathrm{~J}$. B. Goodenough, Magnetism and the chemical bond, Wiley, New York, 1963.

9 S. Kanungo, B. H. Yan, M. Jansen and C. Felser, Phys. Rev. B: Condens. Matter Mater. Phys., 2014, 89, 214414.

10 X. D. Ou, Z. W. Li, F. R. Fan, H. B. Wang and H. Wu, Sci. Rep., 2014, 4(7542), 7541-7544.

11 R. Morrow, M. A. McGuire, J. Q. Yan and P. M. Woodward, Inorg. Chem., 2018, 57, 2989-3001.

12 S. Vasala and M. Karppinen, Prog. Solid State Chem., 2015, 43, 1-36.

13 A. E. Smith, A. W. Sleight and M. A. Subramanian, Mater. Res. Bull., 2010, 45, 460-463.

14 P. D. Battle and J. F. Vente, J. Solid State Chem., 1999, 146, 163-167.

15 J. Ting, B. J. Kennedy, Z. Zhang, M. Avdeev, B. Johannessen and L. Y. Jang, Chem. Mater., 2010, 22, 1640-1646.

16 C. Schinzer, J. Phys. Chem. Solids, 2000, 61, 1543-1551.

17 K. Knizek, J. Hejtmanek, M. Marysko, Z. Jirak and J. Bursik, Phys. Rev. B, 2012, 85, 134401.

18 J. Li, A. E. Smith, K. S. Kwong, C. Powell, A. W. Sleight and M. A. Subramanian, J. Solid State Chem., 2010, 183, 13881393.

19 S. V. Streltsov, V. V. Gapontsev and D. I. Khomskii, J. Phys.: Condens. Matter, 2016, 28, 086005.

20 A. C. Larson and R. B. Von Dreele, Los Alamos National Laboratory Report LAUR 86-748, 2000. 
21 K. Lagarec and D. G. Rancourt, Recoil: Mössbauer spectral analysis software for windows, 1998.

22 J. P. Hodges, S. Short, J. D. Jorgensen, X. Xiong, B. Dabrowski, S. M. Mini and C. W. Kimball, J. Solid State Chem., 2000, 151, 190-209.

23 Y. Takeda, K. Kanno, T. Takada, O. Yamamoto, M. Takano, N. Nakayama and Y. Bando, J. Solid State Chem., 1986, 63, 237-249.

24 E. N. K. Glover, S. G. Ellington, G. Sankar and R. G. Palgrave, J. Mater. Chem. A, 2016, 4, 6946-6954.

25 T. K. Le, D. Flahaut, H. Martinez, N. Andreu, D. Gonbeau, E. Pachoud, D. Pelloquin and A. Maignan, J. Solid State Chem., 2011, 184, 2387-2392.

26 M. C. Biesinger, B. P. Payne, A. P. Grosvenor, L. W. M. Lau, A. R. Gerson and R. S. Smart, Appl. Surf. Sci., 2011, 257, 2717-2730.

27 T. Yamashita and P. Hayes, Appl. Surf. Sci., 2008, 254, 24412449.

28 E. S. Ilton, J. E. Post, P. J. Heaney, F. T. Ling and S. N. Kerisit, Appl. Surf. Sci., 2016, 366, 475-485.

29 B. Bakowski, P. D. Battle, E. J. Cussen, L. D. Noailles, M. J. Rosseinsky, A. I. Coldea and J. Singleton, Chem. Commun., 1999, 2209-2210.

30 N. Kamegashira, Y. Miyazaki and H. Yamamoto, Mater. Chem. Phys., 1984, 11, 187-194.
31 K. Kuroda, K. Shinozaki, K. Uematsu, N. Mizutani and M. Kato, J. Am. Ceram. Soc., 1980, 63, 109110.

32 H. J. Gysling, J. R. Monnier and G. Apai, J. Catal., 1987, 103, 407-418.

33 K. Yamaura and E. Takayama-Muromachi, Phys. Rev. B, 2001, 64, 224424.

34 C. Schinzer and G. Demazeau, J. Mater. Sci., 1999, 34, 251256.

35 J. Blasco, J. Garcia, J. Campo, M. C. Sanchez and G. Subias, Phys. Rev. B, 2002, 66, 174431.

36 E. J. Cussen, M. J. Rosseinsky, P. D. Battle, J. C. Burley, L. E. Spring, J. F. Vente, S. J. Blundell, A. I. Coldea and J. Singleton, J. Am. Chem. Soc., 2001, 123, 11111122.

37 J. Goodenough, R. J. Arnott, N. Menyuk and A. Wold, Phys. Rev., 1961, 124, 373-384.

38 M. T. Haque, H. Satoh and N. Kamegashira, J. Alloys Compd, 2005, 390, 115-121.

39 P. D. Battle, T. C. Gibb, C. W. Jones and F. Studer, J. Solid State Chem., 1989, 78, 281-293.

40 P. D. Battle, S. K. Bollen and A. V. Powell, J. Solid State Chem., 1992, 99, 267-275.

41 A. Halder, D. Nafday, P. Sanyal and T. Saha-Dasgupta, npj Quantum Mater., 2018, 3, 17. 